\title{
Resveratrol protects rabbit ventricular myocytes against oxidative stress-induced arrhythmogenic activity and $\mathrm{Ca}^{2+}$ overload
}

\author{
Wei $\mathrm{LI}^{1}$, Yue-peng WANG ${ }^{1}$, Ling GAO ${ }^{2}$, Peng-pai ZHANG ${ }^{1}$, Qing ZHOU ${ }^{1}$, Quan-fu XU ${ }^{1}$, Zhi-wen ZHOU ${ }^{1}$, Kai GUO ${ }^{1}$, Ren-hua \\ $\mathrm{CHEN}^{1}$, Huang-tian YANG ${ }^{2}$, Yi-gang $\mathrm{LI}^{1,}$ * \\ ${ }^{1}$ Department of Cardiology, Xinhua Hospital, Shanghai Jiao Tong University, School of Medicine, Shanghai 200092, China; ${ }^{2}$ Key \\ Laboratory of Stem Cell Biology and Laboratory of Molecular Cardiology, Institute of Health Sciences, Shanghai Jiao Tong University \\ School of Medicine and Shanghai Institutes of Biological Sciences, Chinese Academy of Sciences, Shanghai 200025, China
}

Aim: To investigate whether resveratrol suppressed oxidative stress-induced arrhythmogenic activity and $\mathrm{Ca}^{2+}$ overload in ventricular myocytes and to explore the underlying mechanisms.

Methods: Hydrogen peroxide $\left.\left(\mathrm{H}_{2} \mathrm{O}_{2}, 200 \mu \mathrm{mol} / \mathrm{L}\right)\right)$ was used to induce oxidative stress in rabbit ventricular myocytes. Cell shortening and calcium transients were simultaneously recorded to detect arrhythmogenic activity and to measure intracellular $\mathrm{Ca}^{2+}\left(\left[\mathrm{Ca}^{2+}\right]_{\mathrm{i}}\right)$. $\mathrm{Ca}^{2+} /$ calmodulin-dependent protein kinases II (CaMKII) activity was measured using a CaMKII kit or Western blotting analysis. Voltageactivated $\mathrm{Na}^{+}$and $\mathrm{Ca}^{2+}$ currents were examined using whole-cell recording in myocytes.

Results: $\mathrm{H}_{2} \mathrm{O}_{2}$ markedly prolonged $\mathrm{Ca}^{2+}$ transient duration (CaTD), and induced early afterdepolarization (EAD)-like and delayed afterdepolarization (DAD)-like arrhythmogenic activity in myocytes paced at $0.16 \mathrm{~Hz}$ or $0.5 \mathrm{~Hz}$. Application of resveratrol (30 or $50 \mu \mathrm{mol} / \mathrm{L}$ ) dose-dependently suppressed $\mathrm{H}_{2} \mathrm{O}_{2}$-induced EAD-like arrhythmogenic activity and attenuated CaTD prolongation. Co-treatment with resveratrol $(50 \mu \mathrm{mol} / \mathrm{L})$ effectively prevented both EAD-like and DAD-like arrhythmogenic activity induced by $\mathrm{H}_{2} \mathrm{O}_{2}$. In addition, resveratrol markedly blunted $\mathrm{H}_{2} \mathrm{O}_{2}$-induced diastolic $\left[\mathrm{Ca}^{2+}\right]_{\mathrm{i}}$ accumulation and prevented the myocytes from developing hypercontracture. In whole-cell recording studies, $\mathrm{H}_{2} \mathrm{O}_{2}$ significantly enhanced the late $\mathrm{Na}^{+}$current $\left(I_{\mathrm{Na}, \mathrm{L}}\right)$ and L-type Ca ${ }^{2+}$ current $\left(I_{\mathrm{Ca}, \mathrm{L}}\right)$ in myocytes, which were dramatically suppressed or prevented by resveratrol. Furthermore, $\mathrm{H}_{2} \mathrm{O}_{2}$-induced ROS production and CaMKII activation were significantly prevented by resveratrol.

Conclusion: Resveratrol protects ventricular myocytes against oxidative stress-induced arrhythmogenic activity and $\mathrm{Ca}^{2+}$ overload through inhibition of $I_{\mathrm{Na}, \mathrm{L}} / I_{\mathrm{Ca}, \mathrm{L}}$, reduction of ROS generation, and prevention of CaMKII activation.

Keywords: resveratrol; cardioprotective agents; oxidative stress; cardiac arrhythmias; $\mathrm{Ca}^{2+}$ overload; CaMKII; late sodium current; L-type calcium current

Acta Pharmacologica Sinica (2013) 34: 1164-1173; doi: 10.1038/aps.2013.82; published online 29 Jul 2013

\section{Introduction}

Reactive oxygen species (ROS) are increasingly generated under various pathological conditions, such as ischemia/reperfusion, myocardial infarction, and heart failure. Increased oxidative stress causes a series of detrimental effects on the heart ${ }^{[1]}$. Hydrogen peroxide $\left(\mathrm{H}_{2} \mathrm{O}_{2}\right)$, which can cause oxidative stress, is significantly elevated in hearts exposed to ischemia/reperfusion and predisposes the heart to ischemia/ reperfusion injury and arrhythmias. In myocardial infarction, increasing ROS contribute to left ventricular remodeling and

\footnotetext{
* To whom correspondence should be addressed.

E-mail drliyigang@outlook.com

Received 2013-03-28 Accepted 2013-05-15
}

$\operatorname{arrhythmias}^{[1,2]}$. Increased oxidative stress is also associated with reduced left ventricular function in heart failure ${ }^{[3]}$. The underlying mechanisms may involve an impairment of $\mathrm{Na}$ and Ca homeostasis ${ }^{[4,5]}$, which subsequently causes mechanical dysfunction, arrhythmias and even cell death ${ }^{[6]}$. Recently, $\mathrm{Ca} /$ calmodulin-dependent protein kinase II (CaMKII) has been suggested to be an important mediator of ROS-induced detrimental effects ${ }^{[6,7]}$. ROS activates CaMKII via autophosphorylation- and oxidation-dependent mechanisms ${ }^{[8]}$, which in turn enhance late sodium current $\left(I_{\mathrm{Na}, \mathrm{L}}\right)$ and L-type calcium current $\left(I_{\mathrm{Ca}, \mathrm{L}}\right)$ in cardiac myocytes ${ }^{[6,9]}$. Augmentation of $I_{\mathrm{Na}, \mathrm{L}}$ and $I_{\mathrm{Ca}, \mathrm{L}}$ not only causes a prolongation of action potential duration (APD) and the occurrence of early afterdepolarizations (EADs) but also leads to sodium and calcium overload, 
contractile dysfunction, the occurrence of delayed afterdepolarizations (DADs) and triggered activities ${ }^{[6,7,10]}$. Despite the serious detrimental effects caused by increased oxidative stress in structural heart diseases, few drugs exist that can be used for clinical treatment.

Resveratrol (trans-3,4',5-trihydroxystilbene) is a natural compound found in abundance in grapes, mulberries, peanuts and red wine ${ }^{[11]}$. Over the past two decades, it has been demonstrated from both in vitro and in vivo studies to have cardioprotective effects, including anti-inflammatory, antioxidative, and anti-hyperlipidemic properties as well as the prevention of platelet aggregation and cardiac hypertrophy ${ }^{[12-14]}$. These beneficial effects of resveratrol may provide explanations for the "French paradox", the finding that the consumption of red wine is associated with a decreased incidence of cardiovascular diseases ${ }^{[15]}$. Recently, studies have revealed that resveratrol can reduce ventricular arrhythmias in myocardial infarction ${ }^{[2,16]}$, ischemia/reperfusion ${ }^{[17]}$, heart failure and other pathological conditions ${ }^{[18]}$. Accumulating evidence indicates that increased oxidative stress is an important factor predisposing the diseased heart to calcium overload and lethal arrhythmias ${ }^{[6,7,10]}$. However, it is unclear whether resveratrol has protective effects against oxidative stress-induced arrhythmias. Therefore, the present study aims to investigate the effects of resveratrol on exogenous $\mathrm{H}_{2} \mathrm{O}_{2}$-induced arrhythmogenic activity and calcium overload and explore the underlying mechanisms.

\section{Materials and methods} Animals

Six-month-old New Zealand White male rabbits weighing 2.0 to $3.0 \mathrm{~kg}$ were used for experiments. Animal care and handling procedures were approved by the Animal Care and Use Committee, Research Institute of Medicine, Shanghai Jiao Tong University, in accordance with the Guide for the Care and Use of Laboratory Animals published by the National Institute of Health (NIH Publication № 85-23, revised 1996).

\section{Materials}

$\mathrm{H}_{2} \mathrm{O}_{2}$ and resveratrol were purchased from Sigma Chemical (St Louis, MO, USA). Resveratrol was dissolved in dimethyl sulfoxide (DMSO) to make a stock solution of $50 \mathrm{mmol} / \mathrm{L}$ with the final concentration of DMSO at less than $0.1 \%$. The same amount of DMSO was added to all groups to exclude the effects of DMSO on myocytes. All experiments were performed at a temperature of $25 \pm 1^{\circ} \mathrm{C}$, unless otherwise mentioned.

\section{Cell isolation}

Ventricular myocytes were enzymatically isolated from the hearts of New Zealand White rabbits as previously described $^{[10]}$.

\section{Measurement of cellular arrhythmias}

$\mathrm{Ca}^{2+}$ transients and cell shortening were simultaneously detected as previously described ${ }^{[19]}$. Freshly isolated rabbit ventricular myocytes were incubated with a $\mathrm{Ca}^{2+}$ indicator, Fura-2 AM ( 2 umol/L; Molecular Probes, Carlsbad, CA, USA), at $25^{\circ} \mathrm{C}$ for $10 \mathrm{~min}$. Loaded cells were electrically stimulated at a pacing cycle length (PCL) of $6 \mathrm{~s}$ or $2 \mathrm{~s}$. Cell shortening was continuously monitored and $\mathrm{Ca}^{2+}$ transients were recorded every $3 \mathrm{~min}$ or when the cellular arrhythmias emerged. Cellular arrhythmias were induced upon addition of $\mathrm{H}_{2} \mathrm{O}_{2}(200$ $\mu \mathrm{mol} / \mathrm{L}$ ). It is generally accepted that after-contractions and after-transients were defined as cellular proarrhythmogenic events, in which early after-transients/contractions (EATs/ EACs) may correspond to EADs and delayed after-transients/ contractions (DATs/DACs) may correspond to DADs ${ }^{[7,20-23]}$. Therefore, EATs/EACs and DATs/DACs can be used as proximal direct indices of EADs-like and DADs-like arrhythmias, respectively. The probabilities of EATs/EACs occurrence were assessed by calculating the percentage of calcium transients or cell shortenings that developed EATs/EACs within 1 min after the treatments $\left(\mathrm{H}_{2} \mathrm{O}_{2}\right.$ and resveratrol) reached steady state. The calcium transient duration (CaTD) was measured as the time from the upstroke to $80 \%$ recovery $\left(i e, \mathrm{CaTD}_{80}\right.$ ).

\section{Measurement of $\left[\mathrm{Ca}^{2+}\right]_{\mathrm{i}}$ and cell shortening}

Myocytes were paced at a frequency of $0.5 \mathrm{~Hz}(\mathrm{PCL}=2 \mathrm{~s})$. The ratio of emitted fluorescence at 340 and $380 \mathrm{~nm}$ was recorded as an indicator of $\left[\mathrm{Ca}^{2+}\right]_{\mathrm{i}}$. Cell shortening was detected using an optical edge detector and collected using a charge-coupled device camera (IonOptix; Milton, MA, USA). The data were analyzed using IonWizard 6.0 software (IonOptix; Milton, MA, USA).

\section{Electrophysiological study}

Whole cell currents $\left(I_{\mathrm{Na}, \mathrm{L}}, I_{\mathrm{Ca}, \mathrm{L}}\right)$ were recorded under voltage clamp mode with an EPC10 amplifier (Heka Electronic, Lambrecht, Pfalz, Germany) as previously described ${ }^{[10,24]}$. Current signals were filtered at $1 \mathrm{kHz}$ and digitized at $10 \mathrm{kHz}$. For $I_{\mathrm{Na}, \mathrm{L}}$ recording, pipettes were filled with an internal solution containing (in mmol/L): $120 \mathrm{CsCl}_{2}, 1.0 \mathrm{CaCl}_{2}, 5 \mathrm{MgCl}_{2}, 5 \mathrm{Na}_{2} \mathrm{ATP}$, 10 TEACl, 11 EGTA, and 10 HEPES (pH 7.2, adjusted with $\mathrm{CsOH}$ ). Myocytes were bathed with a modified Tyrode's solution containing (in mmol/L): $135 \mathrm{NaCl}, 5.4 \mathrm{CsCl}_{2}, 1.8 \mathrm{CaCl}_{2}$, $1 \mathrm{MgCl}_{2}, 0.3 \mathrm{BaCl}_{2}, 0.33 \mathrm{NaH}_{2} \mathrm{PO}_{4}, 10$ glucose, 10 HEPES, and 0.001 nicardipine at $\mathrm{pH}$ 7.3. $I_{\mathrm{Na}, \mathrm{L}}$ was elicited by $300 \mathrm{~ms}$ depolarizing pulses from -120 to $-20 \mathrm{mV}$ at a PCL of $6 \mathrm{~s}$. The amplitude of $I_{\mathrm{Na}, \mathrm{L}}$ was measured at $200 \mathrm{~ms}$ after the initiation of the depolarization step.

To record $I_{\mathrm{C}, \mathrm{L}}$, patch pipettes were filled with an internal solution containing (in mmol/L): 110 Cs-Aspartate, $30 \mathrm{CsCl}$, $5 \mathrm{NaCl}, 10$ HEPES, 0.1 EGTA, $5 \mathrm{MgATP}$ at $\mathrm{pH} 7.2$ adjusted with $\mathrm{CsOH}$, and the cells were superfused with a modified Tyrode's solution in which $\mathrm{KCl}$ was replaced with $\mathrm{CsCl}$. To inactivate the $\mathrm{Na}^{+}$current, the myocytes were stimulated by a $100 \mathrm{~ms}$ prepulse to $-40 \mathrm{mV}$ from the holding potential of -80 $\mathrm{mV}$. Subsequently, $I_{\mathrm{Ca}, \mathrm{L}}$ was elicited by a test depolarization step to $0 \mathrm{mV}$ for $300 \mathrm{~ms}$. The current density was calculated by dividing the amplitude by the cell capacitance. 


\section{Detection of intracellular ROS}

The myocytes were incubated with $5 \mu \mathrm{mol} / \mathrm{L}$ C-DCDHF-DAAM (Invitrogen, Grand Island, NY, USA) for $30 \mathrm{~min}$. After loading, myocytes were washed twice with Tyrode's solution. Loaded myocytes were treated with $\mathrm{H}_{2} \mathrm{O}_{2}(200 \mu \mathrm{mol} / \mathrm{L})$ in the absence or presence of resveratrol $(50 \mu \mathrm{mol} / \mathrm{L})$ for $20 \mathrm{~min}$. Myocytes unexposed to $\mathrm{H}_{2} \mathrm{O}_{2}$ were set as the control group. C-DCDHF-DA can be oxidized by ROS to dichlorofluorescein (DCF), which was used to determine ROS production. Cellular DCF fluorescence intensities were determined by fluorescence microscopy with excitation and emission spectra of 488 and $525 \mathrm{~nm}$, respectively.

\section{Measurement of CaMKII activity}

Isolated myocytes were treated with $\mathrm{H}_{2} \mathrm{O}_{2}(200 \mu \mathrm{mol} / \mathrm{L})$ in the absence or presence of resveratrol $(50 \mu \mathrm{mol} / \mathrm{L})$ for $10 \mathrm{~min}$. Myocytes unexposed to $\mathrm{H}_{2} \mathrm{O}_{2}$ were set as the control group. The CaMKII activity of myocytes was measured with the SignaTECT Calcium/Calmodulin-Dependent Protein Kinase Assay system (Promega, Madison, WI, USA) following the manufacturer's instructions. [ $\left.\gamma^{-}{ }^{32} \mathrm{P}\right] \mathrm{ATP}$ was purchased from PerkinElmer, Inc (Waltham, MA, USA).

\section{Protein preparation and Western blotting}

After intravenous anesthetization with sodium pentobarbital $(30 \mathrm{mg} / \mathrm{kg})$, rabbit hearts were immediately removed and mounted on a Langendorff apparatus and retrogradely perfused through the aorta $(30 \mathrm{~mL} / \mathrm{min})$ with specific solutions depending on the condition for $10 \mathrm{~min}$ at $37^{\circ} \mathrm{C}$ : Tyrode's solution containing vehicle, Tyrode's solution containing 200 $\mu \mathrm{mol} / \mathrm{L} \mathrm{H}_{2} \mathrm{O}_{2}$ and vehicle, and Tyrode's solution containing $200 \mu \mathrm{mol} / \mathrm{L} \mathrm{H}_{2} \mathrm{O}_{2}$ and $50 \mu \mathrm{mol} / \mathrm{L}$ resveratrol. The left ventricular tissue was then isolated and flash frozen in liquid nitrogen. Protein preparations were performed using methods as described previously ${ }^{[25]}$ and the protein contents of CaMKII (antiphospho-CaMKII, 1:1000, Abcam, Cambridge, UK) and glyceraldehyde-3-phosphate dehydrogenase (GAPDH, 1:1000, Beyotime, Haimen, China) in total protein preparations were analyzed by standard Western blotting.

\section{Statistical analysis}

The data are expressed as the mean \pm SEM. Statistical significance was assessed using Student's $t$-tests or ANOVA analysis followed by the Student-Newman-Keuls test. The frequencies of arrhythmia were compared using a chi-squared test. $P<0.05$ was considered statistically significant.

\section{Results}

Resveratrol suppressed and prevented $\mathrm{H}_{2} \mathrm{O}_{2}$-induced arrhythmogenic activity in rabbit ventricular myocytes

Cell shortening and calcium transients were simultaneously recorded from isolated rabbit ventricular myocytes. To stably induce EAD-like arrhythmias, the myocytes were paced at a low frequency $(0.16 \mathrm{~Hz}, \mathrm{PCL}=6 \mathrm{~s})$ as previously described ${ }^{[7]}$. After reaching steady state, the myocytes were continuously perfused with $200 \mu \mathrm{mol} / \mathrm{L} \mathrm{H}_{2} \mathrm{O}_{2}$. As shown in Figure 1A, the exposure of myocytes to $\mathrm{H}_{2} \mathrm{O}_{2}$ led to prolongation of $\mathrm{CaTD}_{80}$ and induction of EATs/EACs, the EAD-like arrhythmias. Most of the cells developed EATs/EACs (90.5\%, 19 out of 21 cells from 10 rabbits) after an average exposure time of $7.4 \pm 0.5$ min with $\mathrm{H}_{2} \mathrm{O}_{2}$. Prolonged exposure to $\mathrm{H}_{2} \mathrm{O}_{2}$ caused continuous EATs/EACs followed by DATs/DACs, the DAD-like arrhythmias. The other two cells (2 of 21 cells, 9.5\%) did not induce EATs /EACs, but directly developed DATs/DACs.

Next, we studied the effects of resveratrol on $\mathrm{H}_{2} \mathrm{O}_{2}$-induced arrhythmogenic activity. When EATs/EACs were induced by $\mathrm{H}_{2} \mathrm{O}_{2}$, addition of resveratrol (30 or $50 \mu \mathrm{mol} / \mathrm{L}$ ) resulted in a significant suppression of the EATs/EACs within 3 to $5 \mathrm{~min}$ (Figure 1B). As summarized in Figure 1D, the probability of EATs/EACs occurrence was significantly reduced by resveratrol at both 50 and $30 \mu \mathrm{mol} / \mathrm{L}$, in a dose-dependent manner (92\% $\pm 2.8 \%$ vs $36 \% \pm 1.2 \%$ and $6 \% \pm 0.8 \%, P<0.05$ and $P<0.01$, respectively). Accordingly, the $\mathrm{CaTD}_{80}$ prolongation induced by $\mathrm{H}_{2} \mathrm{O}_{2}$ was also attenuated by resveratrol. The $\mathrm{CaTD}_{80}$ was increased by $\mathrm{H}_{2} \mathrm{O}_{2}$ from $1055 \pm 72$ to $1892 \pm 154 \mathrm{~ms}$; resveratrol (50 $\mu \mathrm{mol} / \mathrm{L})$ decreased the $\mathrm{CaTD}_{80}$ to $1340 \pm 116 \mathrm{~ms}$ and attenuated by $55 \% \pm 11 \%$ the prolongation of CaTD caused by $\mathrm{H}_{2} \mathrm{O}_{2}$ $(P<0.05, n=8$ cells from 4 rabbits).

Co-treatment of myocytes with resveratrol $(50 \mu \mathrm{mol} / \mathrm{L})$ blunted the prolongation of CaTD caused by $\mathrm{H}_{2} \mathrm{O}_{2}$ and significantly prevented the induction of EATs/EACs (Figure 1C). Although resveratrol could not completely prevent the induction of $\mathrm{H}_{2} \mathrm{O}_{2}$-induced EATs/EACs, it markedly delayed the time for the development of EATs/EACs from 7.4 $\pm 0.5 \mathrm{~min}$ $\left(\mathrm{H}_{2} \mathrm{O}_{2}\right.$ group) to $31 \pm 3 \mathrm{~min}(P<0.01, n=8$ cells from 5 rabbits) (Figure 1E). In addition to preventing the induction of EATs/ EACs caused by $\mathrm{H}_{2} \mathrm{O}_{2}$, resveratrol also prevented the myocytes from developing DATs/DACs (Figure 1C). All myocytes treated with $\mathrm{H}_{2} \mathrm{O}_{2}$ developed DATs/DACs (100\%, 21 of 21 cells from 10 rabbits ), while none of the myocytes treated with resveratrol during exposure to $\mathrm{H}_{2} \mathrm{O}_{2}$ developed these DAD-like arrhythmias within $40 \mathrm{~min}(0 \%, 0$ of 10 cells from 6 rabbits, $P<0.01$ vs $\mathrm{H}_{2} \mathrm{O}_{2}$ ) (Figure $1 \mathrm{~F}$ ). Interestingly, resveratrol completely prevented $\mathrm{H}_{2} \mathrm{O}_{2}$-induced EATs/EACs and DATs/ DACs when the myocytes were paced at a higher frequency $(0.5 \mathrm{~Hz}, \mathrm{PCL}=2 \mathrm{~s})$. At $0.5 \mathrm{~Hz}, \mathrm{H}_{2} \mathrm{O}_{2}$ induced EATs/EACs in 6 out of 11 myocytes $(54.5 \%, P<0.05$ vs at $0.16 \mathrm{~Hz})$ at an average exposure time of $14 \pm 2.7 \mathrm{~min}(P<0.01$ vs at $0.16 \mathrm{~Hz}$ ) (Figure 2A). Meanwhile, $\mathrm{H}_{2} \mathrm{O}_{2}$ induced DATs/DACs in 11 of 11 myocytes $(100 \%)$ within $30 \mathrm{~min}$. Treatment with resveratrol $(50 \mu \mathrm{mol} / \mathrm{L})$ prevented $\mathrm{H}_{2} \mathrm{O}_{2}$-induced EATs/EACs and DATs/DACs for at least $40 \mathrm{~min}\left(P<0.05\right.$ and $P<0.01$ vs $\mathrm{H}_{2} \mathrm{O}_{2}$ group, respectively, $n=10$ cells from 6 rabbits) (Figures 2B-2D).

\section{Resveratrol prevented $\mathrm{H}_{2} \mathrm{O}_{2}$-induced calcium overload and cell death}

$\mathrm{H}_{2} \mathrm{O}_{2}$-induced calcium overload is an important factor causing arrhythmias and cell death. In this series of experiments, the effects of $200 \mu \mathrm{mol} / \mathrm{L} \mathrm{H}_{2} \mathrm{O}_{2}$ on $\left[\mathrm{Ca}^{2+}\right]_{\mathrm{i}}$ and the contractions of rabbit ventricular myocytes were determined in the absence or presence of $50 \mu \mathrm{mol} / \mathrm{L}$ resveratrol (at a PCL of $2 \mathrm{~s}$ ). As shown in Figures $3 \mathrm{~A}$ and $3 \mathrm{~B}, \mathrm{H}_{2} \mathrm{O}_{2}$ led to time-dependent increases 
A

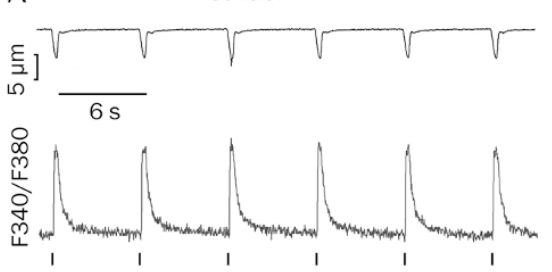

B
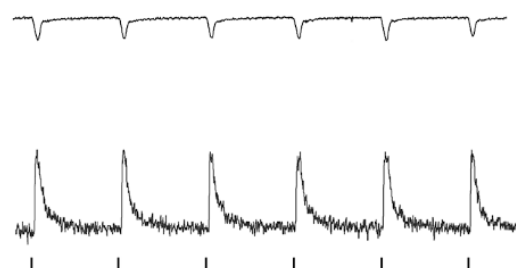

C
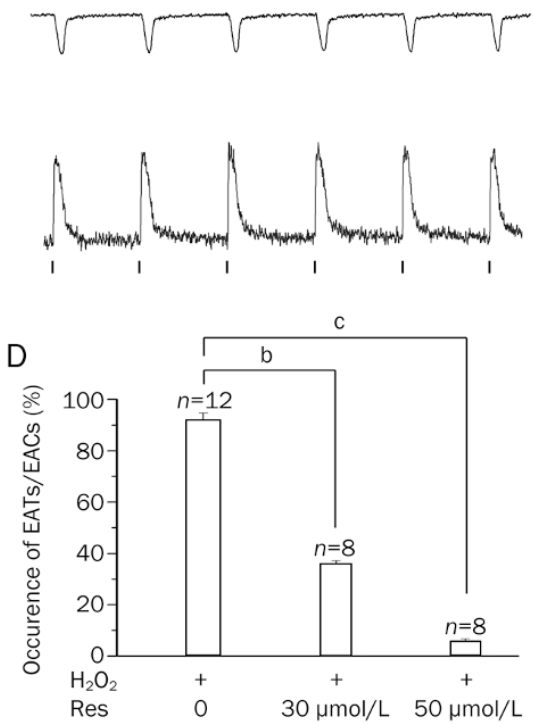
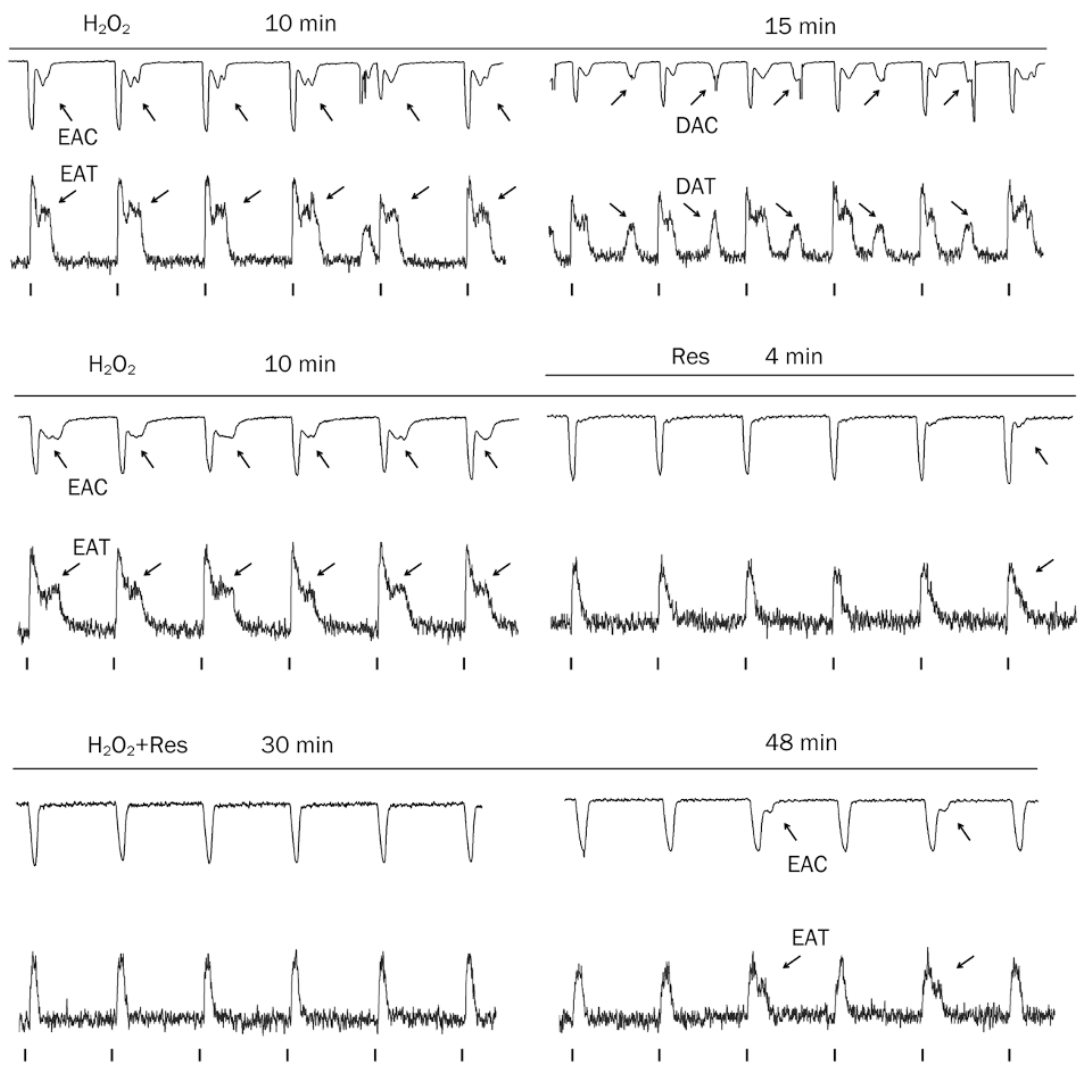

E

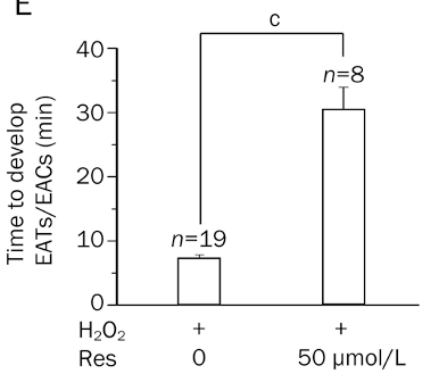

$\mathrm{F}$

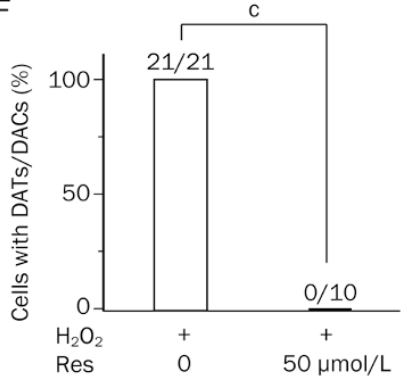

Figure 1. Effects of resveratrol on $\mathrm{H}_{2} \mathrm{O}_{2}$-induced arrhythmogenic activity at $0.16 \mathrm{~Hz}$. In each panel, the top recordings are cell shortening and the bottom ones are calcium transients $\left(\mathrm{PCL}=6 \mathrm{~s}, 0.16 \mathrm{~Hz}\right.$ ). (A) Arrhythmogenic activity induced by $\mathrm{H}_{2} \mathrm{O}_{2}(200 \mu \mathrm{mol} / \mathrm{L})$ in a rabbit ventricular myocyte. Continuous EATs/EACs developed after $10 \mathrm{~min}$ of $\mathrm{H}_{2} \mathrm{O}_{2}$ perfusion. At $15 \mathrm{~min}$, continuous DATs/DACs developed. (B) After EATs/EACs were induced by $200 \mu \mathrm{mol} / \mathrm{L} \mathrm{H}_{2} \mathrm{O}_{2}$, addition of resveratrol (Res, $50 \mu \mathrm{mol} / \mathrm{L}$ ) suppressed EATs/EACs after approximately 4 min. (C) In the presence of resveratrol (Res, $50 \mu \mathrm{mol} / \mathrm{L})$, a myocyte exposed to $\mathrm{H}_{2} \mathrm{O}_{2}(200 \mu \mathrm{mol} / \mathrm{L})$ did not develop EATs/EACs until $48 \mathrm{~min}$ and no DATs/DACs were induced within 48 min. (D) Summarized histogram showing dose-dependent inhibitory effects of resveratrol (Res, 30 and $50 \mu \mathrm{mol} / \mathrm{L}$ ) on the incidence of EATs/EACs induced by $\mathrm{H}_{2} \mathrm{O}_{2}$. (E) Summarized histogram shows the time to develop EATs/EACs in the presence of $\mathrm{H}_{2} \mathrm{O}_{2}$ and $\mathrm{H}_{2} \mathrm{O}_{2}+\mathrm{Res}(50 \mu \mathrm{mol} / \mathrm{L})$. ( $\left.\mathrm{F}\right)$ Summarized histogram shows the proportion of cells displaying DATs/DACs in the presence of $\mathrm{H}_{2} \mathrm{O}_{2}$ and $\mathrm{H}_{2} \mathrm{O}_{2}+\operatorname{Res}(50 \mu \mathrm{mol} / \mathrm{L})$. Mean $\pm \mathrm{SEM}$. ${ }^{\mathrm{b}} P<0.05$, ${ }^{\mathrm{c}} P<0.01$ vs $\mathrm{H}_{2} \mathrm{O}_{2}$.

of diastolic $\left[\mathrm{Ca}^{2+}\right]_{\mathrm{i}}$. Treatment with resveratrol significantly blunted the time-dependent increases of diastolic $\left[\mathrm{Ca}^{2+}\right]_{i}$ during exposure to $\mathrm{H}_{2} \mathrm{O}_{2}$. After a $21 \mathrm{~min}$ incubation of myocytes with $\mathrm{H}_{2} \mathrm{O}_{2}$, diastolic $\left[\mathrm{Ca}^{2+}\right]_{\mathrm{i}}$ was increased to $143 \% \pm 2 \%$ and $114 \% \pm 3 \%$ of the control in the absence and presence of resveratrol, respectively $(P<0.01$; Figure $3 \mathrm{~B})$.

Consistent with this finding, resveratrol prevented hypercontracture caused by $\mathrm{H}_{2} \mathrm{O}_{2}$. As shown in Figure $3 \mathrm{C}, \mathrm{H}_{2} \mathrm{O}_{2}$ induced calcium overload led to the development of hyper- contracture, which is a permanent reduction $(<50 \%)$ of the longitudinal cell length attributable to a persistent activation of myofilaments ${ }^{[6]}$. $\mathrm{H}_{2} \mathrm{O}_{2}$ caused the development of hypercontracture within $21 \pm 1.3 \mathrm{~min}$ ( $n=43$ cells from 10 rabbits). However, in the presence of resveratrol, myocytes $(n=22$ cells from 8 rabbits) exposed to $\mathrm{H}_{2} \mathrm{O}_{2}$ never developed hypercontracture within $40 \mathrm{~min}$. A Kaplan-Meier survival analysis (Figure 3D) revealed that resveratrol effectively prevented ROS-induced hypercontracture and cell death. 


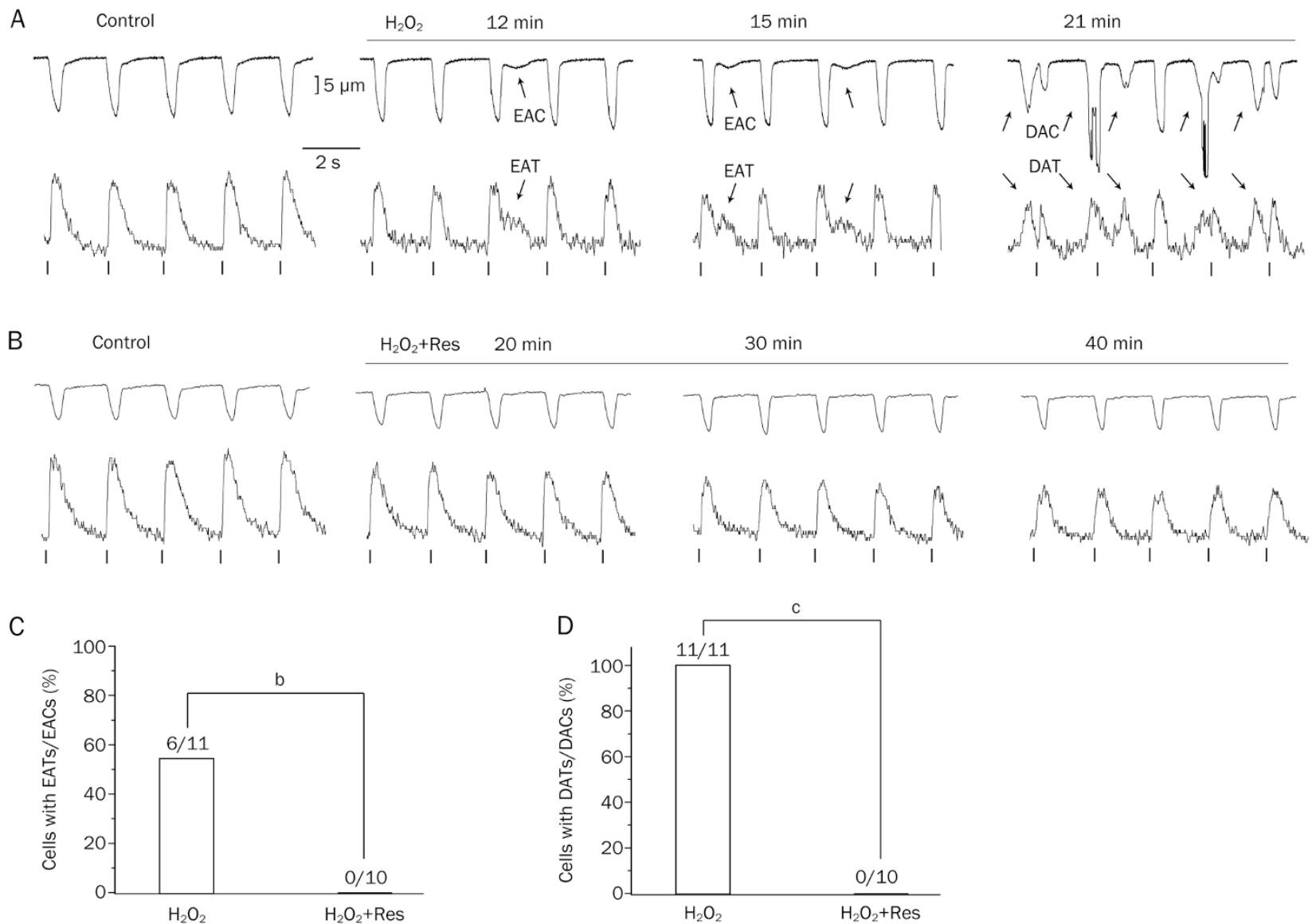

Figure 2. Effects of resveratrol on $\mathrm{H}_{2} \mathrm{O}_{2}$-induced arrhythmogenic activity at $0.5 \mathrm{~Hz}$. In each panel, the top recordings are cell shortening and the bottom ones are calcium transients $\left(\mathrm{PCL}=2 \mathrm{~s}, 0.5 \mathrm{~Hz}\right.$ ). (A) Arrhythmogenic activity induced by $\mathrm{H}_{2} \mathrm{O}_{2}(200 \mu \mathrm{mol} / \mathrm{L})$ in rabbit ventricular myocytes. (B) In the presence of resveratrol (Res, $50 \mu \mathrm{mol} / \mathrm{L})$, myocytes exposed to $\mathrm{H}_{2} \mathrm{O}_{2}(200 \mu \mathrm{mol} / \mathrm{L})$ did not develop EATs/EACs and DATs/DACs for at least 40 min. (C) Summarized histogram shows proportion of cells displaying EATs/EACs in the presence of $\mathrm{H}_{2} \mathrm{O}_{2}$ and $\mathrm{H}_{2} \mathrm{O}_{2}+$ Res (50 $\mu$ mol/L). (D) Summarized histogram shows proportion of cells displaying DATs/DACs in the presence of $\mathrm{H}_{2} \mathrm{O}_{2}$ and $\mathrm{H}_{2} \mathrm{O}_{2}+\operatorname{Res}(50 \mu \mathrm{mol} / \mathrm{L})$. Mean $\pm \mathrm{SEM}$. ${ }^{b} P<0.05,{ }^{c} P<0.01$ vs $\mathrm{H}_{2} \mathrm{O}_{2}$.

\section{Resveratrol inhibited ROS-induced $I_{\mathrm{Na}, \mathrm{L}}$ augmentation}

It has been reported previously ${ }^{[6,7,10]}$ that augmentation of $I_{\mathrm{Na}, \mathrm{L}}$ plays a key role in ROS-induced cellular $\mathrm{Na}^{+}$and $\mathrm{Ca}^{2+}$ overload and arrhythmias. Therefore, we first examined whether resveratrol could inhibit ROS-induced $I_{\mathrm{Na}, \mathrm{L}}$ augmentation. When myocytes were exposed to $\mathrm{H}_{2} \mathrm{O}_{2}, I_{\mathrm{Na}, \mathrm{L}}$ gradually increased in a time-dependent manner and reached a steady state at approximately 10-14 min after $\mathrm{H}_{2} \mathrm{O}_{2}$ treatment. Treatment with resveratrol markedly prevented the time-dependent increase of $I_{\mathrm{Na}, \mathrm{L}}$ induced by $\mathrm{H}_{2} \mathrm{O}_{2}$ (Figure $4 \mathrm{~A}$ ). At the point of 12 min after $\mathrm{H}_{2} \mathrm{O}_{2}$ exposure, $I_{\mathrm{Na}, \mathrm{L}}$ increased from $-0.31 \pm 0.014$ $\mathrm{pA} / \mathrm{pF}$ to $-1.06 \pm 0.037 \mathrm{pA} / \mathrm{pF}$ in the $\mathrm{H}_{2} \mathrm{O}_{2}$ group, increased by $245 \% \pm 23 \%$ ( $n=6$ cells from 4 rabbits). While in the resveratrol treatment group, $I_{\mathrm{Na}, \mathrm{L}}$ increased from $-0.31 \pm 0.032 \mathrm{pA} / \mathrm{pF}$ to $-0.53 \pm 0.028 \mathrm{pA} / \mathrm{pF}$, only a $75 \% \pm 11 \%$ increase of $I_{\mathrm{Na}, \mathrm{L}}(n=6$ cells from 4 rabbits, $P<0.01$, Figure $4 \mathrm{~B})$. Resveratrol also reversed the $\mathrm{H}_{2} \mathrm{O}_{2}$-induced $I_{\mathrm{Na}, \mathrm{L}}$ augmentation (Figure $4 \mathrm{C}$ ). $I_{\mathrm{Na}, \mathrm{L}}$ increased from $-0.31 \pm 0.013 \mathrm{pA} / \mathrm{pF}$ to $-1.07 \pm 0.045 \mathrm{pA} / \mathrm{pF}$ after the incubation of myocytes with $\mathrm{H}_{2} \mathrm{O}_{2}(P<0.05, n=6$ cells from 5 rabbits). The addition of resveratrol reduced the current to $-0.53 \pm 0.031 \mathrm{pA} / \mathrm{pF}$ in the presence of $\mathrm{H}_{2} \mathrm{O}_{2}(P<0.05$; Figure $4 \mathrm{D})$, a $178 \% \pm 17 \%$ decrease of the $\mathrm{H}_{2} \mathrm{O}_{2}$-induced $I_{\mathrm{Na}, \mathrm{L}}$.

\section{Resveratrol inhibited ROS-induced $I_{\mathrm{Ca}, \mathrm{L}}$ augmentation}

Because reactivation of $I_{\mathrm{Ca}, \mathrm{L}}$ contributes to the $\mathrm{H}_{2} \mathrm{O}_{2}$-induced EAD in rabbit ventricular myocytes ${ }^{[7]}$, we next investigated the potential involvement of $I_{\mathrm{Ca}, \mathrm{L}}$ in the inhibitory effect of resveratrol on $\mathrm{H}_{2} \mathrm{O}_{2}$-induced EATs/EACs. As shown in Figures $5 \mathrm{~A}$ and $5 \mathrm{~B}, \mathrm{H}_{2} \mathrm{O}_{2}$ increased $I_{\mathrm{Ca}, \mathrm{L}}$ from $-8.2 \pm 0.8 \mathrm{pA} / \mathrm{pF}$ to $-12.3 \pm 1.4$ $\mathrm{pA} / \mathrm{pF}(P<0.05, n=6$ cells from 4 rabbits $)$ and resveratrol reduced the current to $-9.1 \pm 0.8 \mathrm{pA} / \mathrm{pF}(P<0.05)$, indicating that resveratrol markedly inhibited $\mathrm{H}_{2} \mathrm{O}_{2}$-induced $I_{\mathrm{Ca}, \mathrm{L}}$ augmentation.

\section{Resveratrol reduced $\mathrm{H}_{2} \mathrm{O}_{2}$-induced $\mathrm{ROS}$ production}

To determine whether resveratrol inhibits the arrhythmogenic activity and calcium overload via decreasing intracellular ROS, the effect of resveratrol on intracellular ROS levels was measured. ROS production was monitored by detecting the fluorescence from the reaction of intracellular ROS with C-DCDHF-DA using fluorescence microscopy. As shown in Figures 6A and 6B, DCF fluorescence intensity was signifi- 

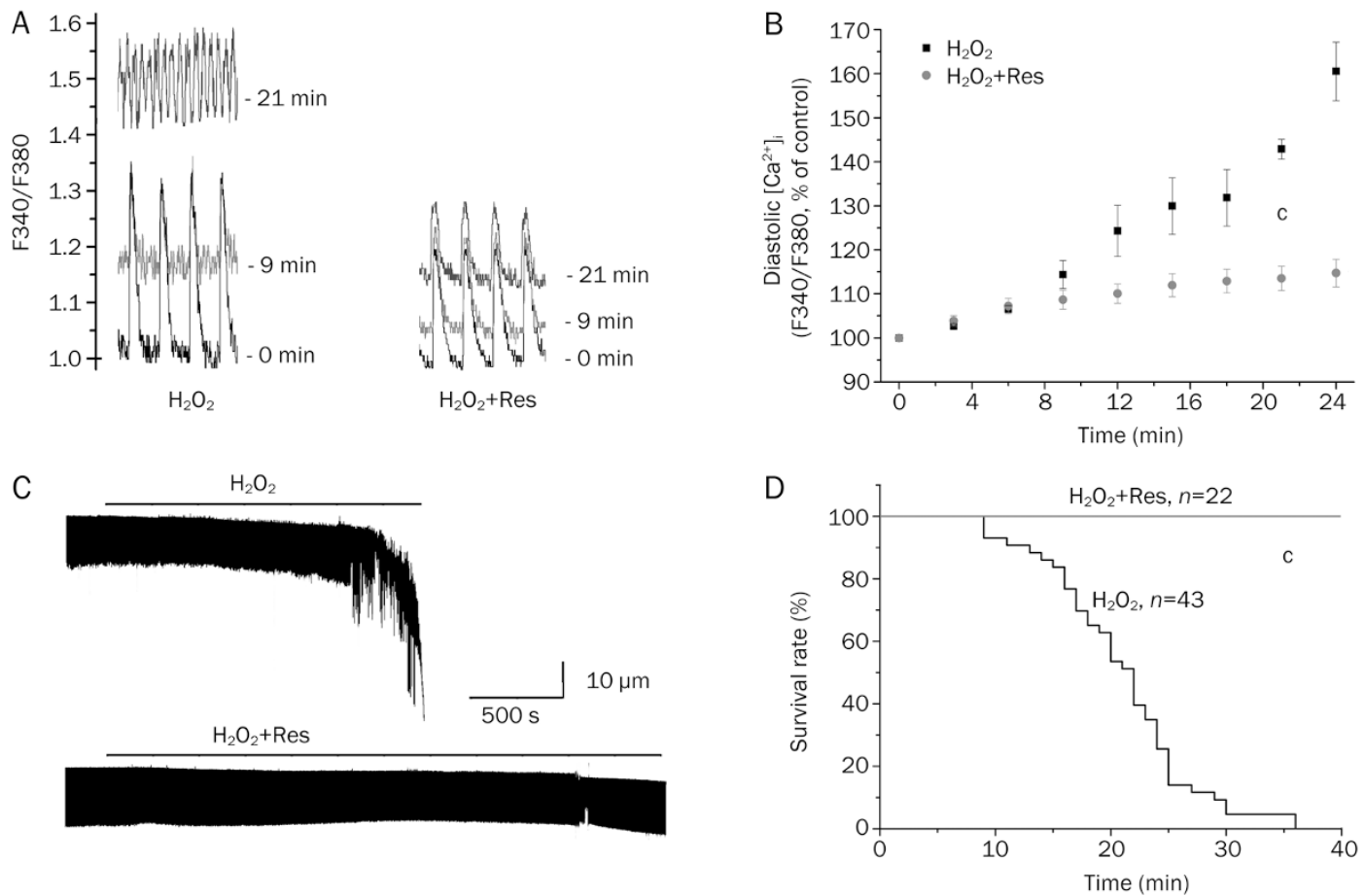

Figure 3. Effects of resveratrol on $\mathrm{H}_{2} \mathrm{O}_{2}$-induced calcium overload and hypercontracture. In this part, cells were paced at $0.5 \mathrm{~Hz}$ (PCL=2 s). (A) Original traces of $\mathrm{Ca}^{2+}$ transient in the absence and presence of $50 \mu \mathrm{mol} / \mathrm{L}$ resveratrol (Res) before ( $0 \mathrm{~min}$ ) and after 9 and $21 \mathrm{~min}$ exposures to $200 \mu \mathrm{mol} / \mathrm{L}$ $\mathrm{H}_{2} \mathrm{O}_{2}$. (B) Time course of changes in diastolic $\left[\mathrm{Ca}^{2+}\right]_{\text {, }}$, which was normalized as a percentage of the control (before application of drug). Each point represents data collected from 5 to 10 cells $(n=5-10)$. (C) Representative cell shortening curve of myocytes exposed to $\mathrm{H}_{2} \mathrm{O}_{2}$ in the absence (top) or presence (bottom) of resveratrol (Res, $50 \mu \mathrm{mol} / \mathrm{L}$ ). (D) Kaplan-Meier analysis of hypercontracture development. ${ }^{\mathrm{c}} \mathrm{P}<0.01$ vs $\mathrm{H}_{2} \mathrm{O}_{2}$ group.

cantly increased after a 20 min exposure with $\mathrm{H}_{2} \mathrm{O}_{2}$. Treatment with resveratrol significantly decreased the generation of ROS $\left(P<0.05\right.$ vs $\mathrm{H}_{2} \mathrm{O}_{2}$ group).

\section{Resveratrol prevented $\mathrm{H}_{2} \mathrm{O}_{2}$-induced CaMKII activation}

It has been reported that ROS can markedly activate CaMKII ${ }^{[6]}$. Having confirmed that resveratrol reduced ROS production, we next tested whether ROS-induced CaMKII activation could be prevented by resveratrol. Using a CaMKII assay kit, we found that $\mathrm{H}_{2} \mathrm{O}_{2}(200 \mu \mathrm{mol} / \mathrm{L})$ effectively increased CaMKII activity and resveratrol $(50 \mu \mathrm{mol} / \mathrm{L})$ significantly prevented this activation in isolated myocytes $\left(P<0.05\right.$ vs $\mathrm{H}_{2} \mathrm{O}_{2}$ group; Figure 7A). With a Western blotting analysis using the antibody against p-CaMKII, we further confirmed that resveratrol prevented $\mathrm{H}_{2} \mathrm{O}_{2}$-induced CaMKII activation. As shown in Figures 7B and 7C, CaMKII phosphorylation was significantly increased in hearts perfused with $200 \mu \mathrm{mol} / \mathrm{L} \mathrm{H}_{2} \mathrm{O}_{2}$ for $10 \mathrm{~min}$ $(P<0.05$ vs control), and resveratrol decreased the activation of CaMKII $\left(P<0.05\right.$ vs $\mathrm{H}_{2} \mathrm{O}_{2}$ group).

\section{Discussion}

The cardioprotective effects of resveratrol are complex and are not completely understood. In the present study, we provide the first evidence showing that resveratrol prevents and suppresses oxidative stress-induced arrhythmogenic activity. It also prevents oxidative stress-induced calcium overload and cell death. Furthermore, our study suggests that the underlying mechanisms involve: (1) inhibition of $I_{\mathrm{Na}, \mathrm{L}} / I_{\mathrm{Ca}, \mathrm{L}}$; (2) reduction of ROS generation; and (3) prevention of CaMKII activation.

EAD-mediated triggered activity plays an important role in ROS-induced arrhythmias ${ }^{[26]}$. In this study, we observed that resveratrol significantly suppressed and prevented $\mathrm{H}_{2} \mathrm{O}_{2}$-induced EATs/EACs, ie, EAD-like arrhythmias. At $0.16 \mathrm{~Hz}$ (PCL $6 \mathrm{~s}$ ), resveratrol markedly delayed the time to develop EATs/EACs. It also reversed $\mathrm{H}_{2} \mathrm{O}_{2}$-induced EATs/ EACs when added after EATs/EACs were induced. Recent studies $^{[7,10]}$ have implicated that ROS-activated CaMKII mediates EAD formation. Downstream targets of ROS include CaMKII, $I_{\mathrm{Ca}, \mathrm{L}}$, and $I_{\mathrm{Na}, \mathrm{L}}$. ROS-activated CaMKII causes $I_{\mathrm{Ca}, \mathrm{L}}$ and $I_{\mathrm{Na}, \mathrm{L}}$ augmentation through the regulation of calcium and sodium channel phosphorylation sites ${ }^{[27]}$. Xie et $a l^{[7,10]}$ have demonstrated that both $I_{\mathrm{Ca}, \mathrm{L}}$ and $I_{\mathrm{Na}, \mathrm{L}}$ are required for ROSinduced EAD formation: activation of late $I_{\mathrm{Na}}$ to reduce the repolarization reserve (ie, to prolong APD) and the modification of $I_{\mathrm{Ca}, \mathrm{L}}$ to enhance its reactivation properties to generate the EAD upstroke. In the present study, we found that resveratrol effectively reduced $\mathrm{H}_{2} \mathrm{O}_{2}$-induced ROS generation. With a CaMKII assay kit, we showed that resveratrol significantly prevented $\mathrm{H}_{2} \mathrm{O}_{2}$-induced CaMKII activation in isolated myocytes. Using CaMKII phosphorylation at threonine-287 as a marker of CaMKII activity, we further confirmed that resvera- 
A

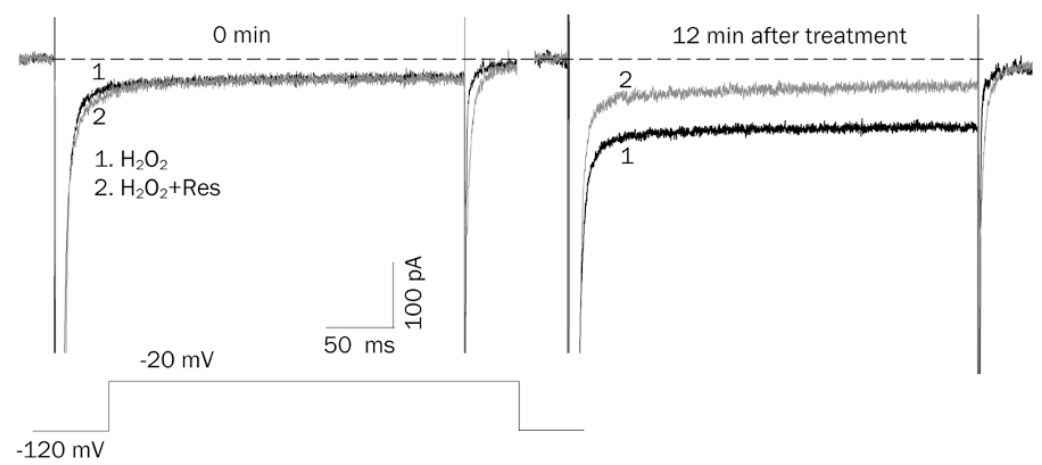

B Time (min)

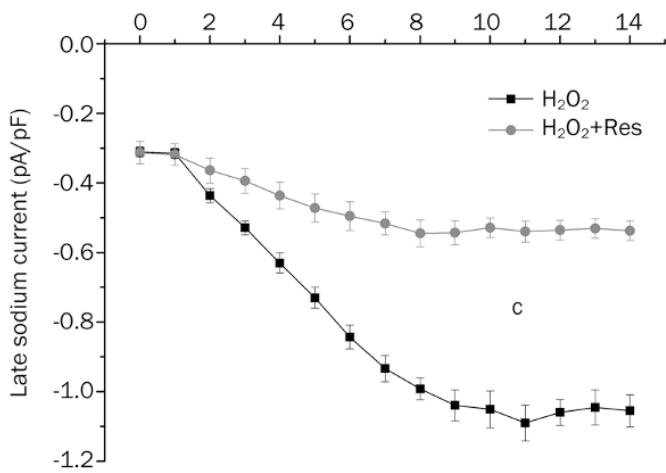

C

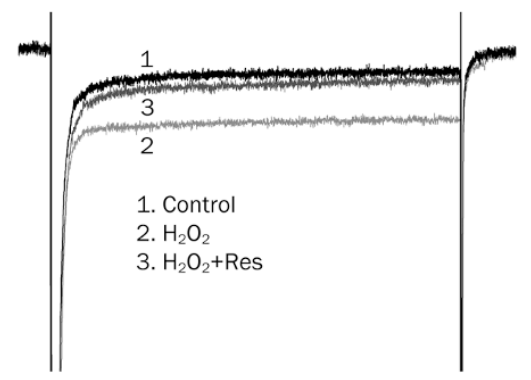

D

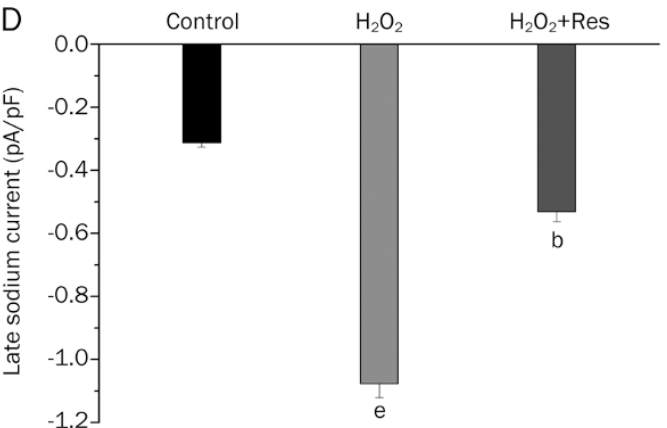

Figure 4. Effects of resveratrol on $\mathrm{H}_{2} \mathrm{O}_{2}$-induced $I_{\mathrm{Na}, \mathrm{L}}$ augmentation. $I_{\mathrm{Na}, \mathrm{L}}$ was measured at a PCL of $6 \mathrm{~s}$ (protocol in inset) in isolated rabbit myocytes. Original traces (A) and mean data (B) showed that $\mathrm{H}_{2} \mathrm{O}_{2}$ significantly increased $I_{\mathrm{Na}, \mathrm{L}}$ in myocytes. This increase was significantly prevented by resveratrol (Res, $50 \mu \mathrm{mol} / \mathrm{L}$ ). Original traces $(\mathrm{C})$ and mean data (D) showed that resveratrol (Res, $50 \mu \mathrm{mol} / \mathrm{L}$ ) reversed the $\mathrm{H}_{2} \mathrm{O}_{2}$-induced $I_{\mathrm{Na}, \mathrm{L}}$ augmentation. ${ }^{\mathrm{b}} P<0.05,{ }^{\mathrm{c}} P<0.01$ vs $\mathrm{H}_{2} \mathrm{O}_{2}$ group. ${ }^{\mathrm{e}} P<0.05$ vs control. Mean \pm SEM. $n=6$ for each group.
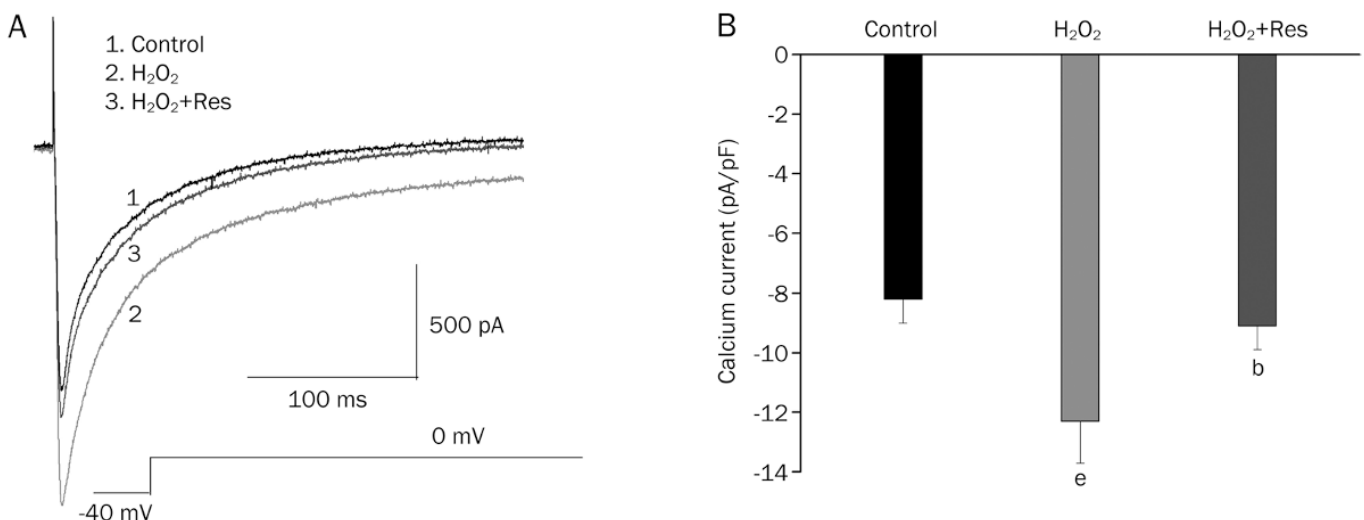

Figure 5. Effects of resveratrol on $\mathrm{H}_{2} \mathrm{O}_{2}$-induced $I_{\text {Ca,L }}$ augmentation. (A) Representative $I_{\text {Ca,L }}$ traces under control conditions, in the presence of $\mathrm{H}_{2} \mathrm{O}_{2}$, and $\mathrm{H}_{2} \mathrm{O}_{2}+$ resveratrol (Res, $50 \mu \mathrm{mol} / \mathrm{L}$ ). (B) A bar graph summarizing the $\mathrm{H}_{2} \mathrm{O}_{2}$-induced increase of $I_{\text {Ca, }}$, which is significantly suppressed by resveratrol (Res, $50 \mu \mathrm{mol} / \mathrm{L}) .{ }^{\mathrm{b}} \mathrm{P}<0.05$ vs $\mathrm{H}_{2} \mathrm{O}_{2}$. ${ }^{\mathrm{e}} \mathrm{P}<0.05$ vs control. Mean \pm SEM. $n=6$.

trol significantly prevented $\mathrm{H}_{2} \mathrm{O}_{2}$-induced CaMKII activation in rabbit hearts. By reduction of ROS generation and CaMKII activation, resveratrol may indirectly inhibit $I_{\mathrm{Na}, \mathrm{L}}$ and $I_{\mathrm{Ca}, \mathrm{L}}$ and subsequently prevent and suppress $\mathrm{H}_{2} \mathrm{O}_{2}$-induced EATs/ EACs. Previous studies ${ }^{[16,28]}$ have reported that resveratrol can directly modulate ion channels. For instance, resveratrol can inhibit $I_{\mathrm{Ca}, \mathrm{L}}$ and enhance the ATP-sensitive potassium current $\left(I_{\mathrm{K}, \mathrm{ATP}}\right)$ in isolated ventricular myocytes ${ }^{[16]}$. It can also inhibit the sodium current $\left(I_{\mathrm{Na}}\right)$, transient $\left(I_{\mathrm{to}}\right)$ and sustain $\left(I_{\mathrm{ss}}\right)$ outward potassium currents ${ }^{[17]}$. Therefore, we cannot rule out the possibility that a direct inhibition of $I_{\mathrm{Na}, \mathrm{L}}$ and $I_{\mathrm{Ca}, \mathrm{L}}$ by resveratrol contributes to its inhibition of EATs/EACs. 


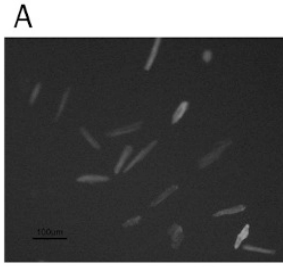

Control

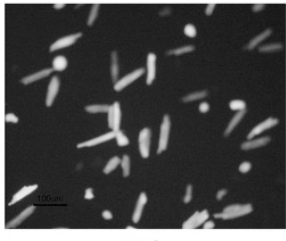

$\mathrm{H}_{2} \mathrm{O}_{2}$

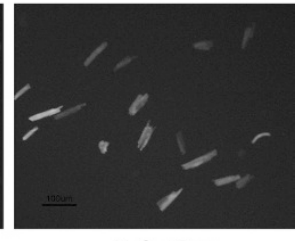

$\mathrm{H}_{2} \mathrm{O}_{2}+$ Res
B

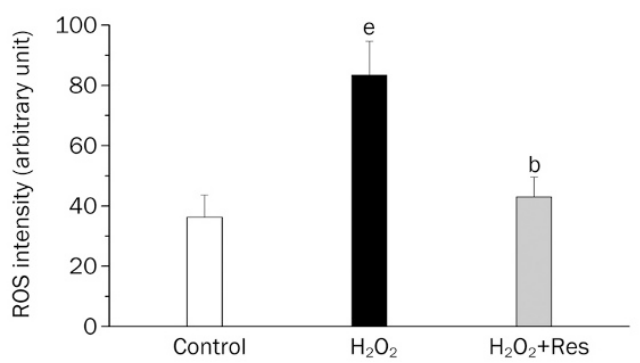

Figure 6. Effects of resveratrol on $\mathrm{H}_{2} \mathrm{O}_{2}$-induced ROS production. (A) DCF fluorescence images of myocytes exposed to $\mathrm{H}_{2} \mathrm{O}_{2}(200 \mu \mathrm{mol} / \mathrm{L})$ in the absence and presence of resveratrol (Res, $50 \mu \mathrm{mol} / \mathrm{L}$ ). (B) DCF fluorescence intensity measured as the image optical density (IOD) per unit area. ${ }^{\mathrm{b}} \mathrm{P}<0.05$ vs $\mathrm{H}_{2} \mathrm{O}_{2}$. ${ }^{\mathrm{e}} \mathrm{P}<0.05$ vs control. Mean \pm SEM. $n=3$.

Interestingly, when myocytes were paced at a higher frequency $(0.5 \mathrm{~Hz}$, at a PCL of $2 \mathrm{~s})$, resveratrol completely prevented the $\mathrm{H}_{2} \mathrm{O}_{2}$-induced EATs/EACs for at least $40 \mathrm{~min}$, indicating that resveratrol has enhanced anti-arrhythmias properties at a higher frequency. This may be due to a larger $I_{\mathrm{Na}, \mathrm{L}}$ at lower frequencies ${ }^{[24,29]}$, which makes myocytes more prone to EATs/EACs. In sinus rhythm, $I_{\mathrm{Na}, \mathrm{L}}$ is much smaller than it is at $0.16 \mathrm{~Hz}$. Thus, resveratrol may be expected to be more effective in preventing $\mathrm{H}_{2} \mathrm{O}_{2}$-induced EATs/EACs under sinus rhythm.

Calcium overload is an important factor causing DADinduced arrhythmias and cell death ${ }^{[6]}$. In this study, we showed that resveratrol significantly blunted time-dependent $\left[\mathrm{Ca}^{2+}\right]_{\mathrm{i}}$ increase induced by $\mathrm{H}_{2} \mathrm{O}_{2}$. As a result, resveratrol prevented $\mathrm{H}_{2} \mathrm{O}_{2}$-induced hypercontracture and cell death. Accordingly, resveratrol completely prevented the development of DATs/DACs, the DAD-like arrhythmias. Recent studies indicate that CaMKII activation and $I_{\mathrm{Na}, \mathrm{L}}$ augmentation play important roles in the ROS-induced $\mathrm{Ca}^{2+}$ overload and arrhythmias ${ }^{[4]}$. Under various cardiac pathological conditions, there exists a lethal cycle between CaMKII and $I_{\mathrm{Na}, \mathrm{L}}{ }^{[30,31]}$. ROS dramatically enhances $I_{\mathrm{Na}, \mathrm{L}}$ via CaMKII activation; the enhanced $I_{\mathrm{Na}, \mathrm{L}}$ further activates CaMKII, leading to CaMKII over-activation $^{[6,30]}$. Consequently, on the one hand, the ROSinduced over-activation of CaMKII phosphorylates RyR2 and causes sarcoplasmic reticulum (SR) calcium leak ${ }^{[32]}$; on the other hand, the CaMKII activation-enhanced $I_{\mathrm{Na}, \mathrm{L}}$ leads to sodium overload and subsequently calcium overload via the $\mathrm{NCX}^{[4]}$. Calcium overload and SR calcium leak always induce arrhythmogenic calcium wave and cause DAD-like $\operatorname{arrhythmias}^{[22]}$. Additionally, calcium overload leads to the
A

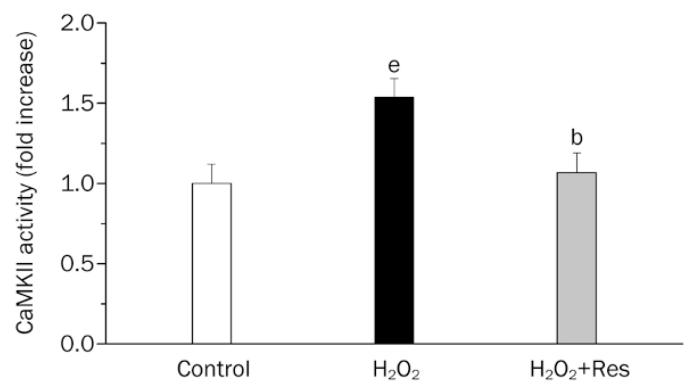

B

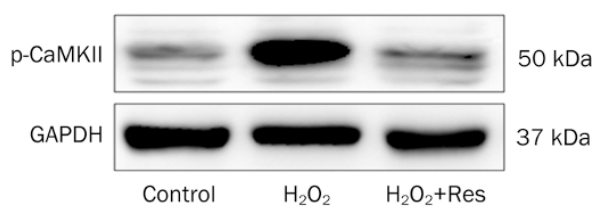

C

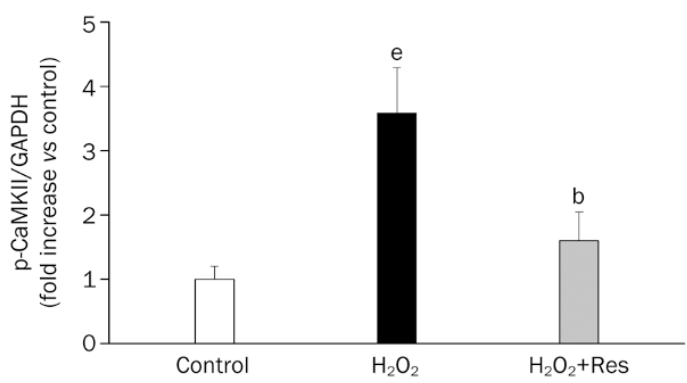

Figure 7. Effects of resveratrol on $\mathrm{H}_{2} \mathrm{O}_{2}$-induced CaMKII activation. (A) Histograms illustrating the CaMKII activity in response to a $10 \mathrm{~min}$ exposure to $200 \mu \mathrm{mol} / \mathrm{L} \mathrm{H}_{2} \mathrm{O}_{2}$ in the absence or presence of resveratrol (Res, $50 \mu \mathrm{mol} / \mathrm{L}$ ). ${ }^{b} P<0.05$ vs $\mathrm{H}_{2} \mathrm{O}_{2}$. ${ }^{e} P<0.05$ vs control. $n=4$. (B) Western blotting analysis showing the levels of phosphorylated CaMKII in response to a $10 \mathrm{~min}$ exposure to $200 \mu \mathrm{mol} / \mathrm{L} \mathrm{H}_{2} \mathrm{O}_{2}$ in the absence or presence of resveratrol (Res, $50 \mu \mathrm{mol} / \mathrm{L})$. (C) Mean data of CaMKII phosphorylation normalized to the total amount of GAPDH from 3 experiments. ${ }^{b} P<0.05$ vs $\mathrm{H}_{2} \mathrm{O}_{2}$. ${ }^{\text {e}} P<0.05$ vs control. Mean \pm SEM. $n=3$.

development of hypercontracture and cell death ${ }^{[6]}$. Therefore, elevated ROS leads to the development of a lethal cycle between CaMKII and $I_{\mathrm{Na}, \mathrm{L}}$ in diseased hearts. In the present study, we showed that resveratrol prevented $\mathrm{H}_{2} \mathrm{O}_{2}$-induced CaMKII activation and augmentation of $I_{\mathrm{Na}, \mathrm{L}}$ and effectively blocked the lethal cycle between them. Thus, resveratrol prevented the $\mathrm{H}_{2} \mathrm{O}_{2}$-induced calcium overload and DAD-like arrhythmias. In addition, ROS can directly oxidize RyR2 ${ }^{[33]}$, leading to an increased calcium spark, DAD-like arrhythmias and calcium overload. By reducing ROS generation, resveratrol may reduce RyR2 oxidization and also suppress DAD-like arrhythmias and calcium overload.

A limitation of the present study was that we did not investigate the anti-arrhythmias properties of resveratrol at the organ/whole heart level. This requires further study in the future.

In conclusion, resveratrol significantly suppressed and prevented oxidative stress-induced arrhythmogenic activity and calcium overload by inhibition of $I_{\mathrm{Na}, \mathrm{L}} / I_{\mathrm{Ca}, \mathrm{L}}$ reduction of ROS 
generation, and prevention of CaMKII activation. This study provides a new way to treat arrhythmias and calcium overload induced by ROS. It also provides a novel drug to prevent CaMKII over-activation, a hallmark of pathological conditions, such as heart failure.

\section{Acknowledgements}

This work was supported by grants from the National Natural Science Foundation of China (№ 81070154, 81270258, and 81170302).

\section{Author contribution}

Yi-gang LI and Yue-peng WANG designed the research; Wei LI, Ling GAO, Peng-pai ZHANG, Qing ZHOU, and Quan-fu XU performed the research; Zhi-wen ZHOU, Kai GUO, and Ren-hua CHEN analyzed data; Wei LI wrote the paper; Yigang LI, Yue-peng WANG, and Huang-tian YANG revised the manuscript.

\section{References}

1 Kinugawa S, Tsutsui H, Hayashidani S, Ide T, Suematsu N, Satoh $\mathrm{S}$, et al. Treatment with dimethylthiourea prevents left ventricular remodeling and failure after experimental myocardial infarction in mice: role of oxidative stress. Circ Res 2000; 87: 392-8.

2 Xin P, Pan Y, Zhu W, Huang S, Wei M, Chen C. Favorable effects of resveratrol on sympathetic neural remodeling in rats following myocardial infarction. Eur J Pharmacol 2010; 649: 293-300.

3 Mallat Z, Philip I, Lebret M, Chatel D, Maclouf J, Tedgui A. Elevated levels of 8-iso-prostaglandin F2alpha in pericardial fluid of patients with heart failure: a potential role for in vivo oxidant stress in ventricular dilatation and progression to heart failure. Circulation 1998; 97: 1536-9.

4 Song Y, Shryock JC, Wagner S, Maier LS, Belardinelli L. Blocking late sodium current reduces hydrogen peroxide-induced arrhythmogenic activity and contractile dysfunction. J Pharmacol Exp Ther 2006; 318: 214-22.

5 Wagner S, Seidler T, Picht E, Maier LS, Kazanski V, Teucher N, et al. $\mathrm{Na}^{+}-\mathrm{Ca}^{2+}$ exchanger overexpression predisposes to reactive oxygen species-induced injury. Cardiovasc Res 2003; 60: 404-12.

6 Wagner S, Ruff HM, Weber SL, Bellmann S, Sowa T, Schulte T, et al. Reactive oxygen species-activated $\mathrm{Ca} /$ calmodulin kinase Ildelta is required for late $I_{\mathrm{Na}}$ augmentation leading to cellular $\mathrm{Na}$ and $\mathrm{Ca}$ overload. Circ Res 2011; 108: 555-65.

7 Xie LH, Chen F, Karagueuzian HS, Weiss JN. Oxidative-stress-induced afterdepolarizations and calmodulin kinase II signaling. Circ Res 2009; 104: 79-86.

8 Erickson JR, Joiner ML, Guan X, Kutschke W, Yang J, Oddis CV, et al. A dynamic pathway for calcium-independent activation of CaMKII by methionine oxidation. Cell 2008; 133: 462-74.

9 Song $\mathrm{YH}$, Choi E, Park SH, Lee SH, Cho H, Ho WK, et al. Sustained CaMKII activity mediates transient oxidative stress-induced long-term facilitation of L-type $\mathrm{Ca}^{2+}$ current in cardiomyocytes. Free Radic Biol Med 2011; 51: 1708-16.

10 Zhao Z, Fefelova N, Shanmugam M, Bishara P, Babu GJ, Xie LH. Angiotensin II induces afterdepolarizations via reactive oxygen species and calmodulin kinase II signaling. J Mol Cell Cardiol 2011; 50: 128-36.

11 Husken A, Baumert A, Milkowski C, Becker HC, Strack D, Mollers C. Resveratrol glucoside (Piceid) synthesis in seeds of transgenic oilseed rape (Brassica napus L). Theor Appl Genet 2005; 111: 1553-62.

12 Bhat KPL, Kosmeder JW 2nd, Pezzuto JM. Biological effects of resveratrol. Antioxid Redox Signal 2001; 3: 1041-64.

13 Movahed A, Yu L, Thandapilly SJ, Louis XL, Netticadan T. Resveratrol protects adult cardiomyocytes against oxidative stress mediated cell injury. Arch Biochem Biophys 2012; 527: 74-80.

14 Thandapilly SJ, Wojciechowski P, Behbahani J, Louis XL, Yu L, Juric D, et al. Resveratrol prevents the development of pathological cardiac hypertrophy and contractile dysfunction in the SHR without lowering blood pressure. Am J Hypertens 2010; 23: 192-6.

15 Renaud S, de Lorgeril M. Wine, alcohol, platelets, and the French paradox for coronary heart disease. Lancet 1992; 339: 1523-6.

16 Chen YR, Yi FF, Li XY, Wang CY, Chen L, Yang XC, et al. Resveratrol attenuates ventricular arrhythmias and improves the long-term survival in rats with myocardial infarction. Cardiovasc Drugs Ther 2008; 22: 479-85.

17 Chen WP, Su MJ, Hung LM. In vitro electrophysiological mechanisms for antiarrhythmic efficacy of resveratrol, a red wine antioxidant. Eur J Pharmacol 2007; 554: 196-204.

18 Lakatta EG, Sollott SJ. The "heartbreak" of older age. Mol Interv 2002; 2: 431-46.

19 Zhang CM, Gao L, Zheng YJ, Yang HT. Berbamine increases myocardial contractility via a $\mathrm{Ca}^{2+}$-independent mechanism. J Cardiovasc Pharmacol 2011; 58: 40-8.

20 Janiak R, Lewartowski B. Early after-depolarisations induced by noradrenaline may be initiated by calcium released from sarcoplasmic reticulum. Mol Cell Biochem 1996; 163-164: 125-30.

21 Sag CM, Wadsack DP, Khabbazzadeh S, Abesser M, Grefe C, Neumann $\mathrm{K}$, et al. Calcium/calmodulin-dependent protein kinase II contributes to cardiac arrhythmogenesis in heart failure. Circ Heart Fail 2009; 2: 664-75.

22 Gonano LA, Sepulveda M, Rico Y, Kaetzel M, Valverde CA, Dedman J, et al. Calcium-calmodulin kinase II mediates digitalis-induced arrhythmias. Circ Arrhythm Electrophysiol 2011; 4: 947-57.

23 Dallas ML, Yang Z, Boyle JP, Boycott HE, Scragg JL, Milligan CJ, et al. Carbon monoxide induces cardiac arrhythmia via induction of the late $\mathrm{Na}^{+}$current. Am J Respir Crit Care Med 2012; 186: 648-56.

24 Wu L, Ma J, Li H, Wang C, Grandi E, Zhang P, et al. Late sodium current contributes to the reverse rate-dependent effect of IKr inhibition on ventricular repolarization. Circulation 2011; 123: 1713-20.

25 Qi X, Yeh YH, Chartier D, Xiao L, Tsuji Y, Brundel BJ, et al. The calcium/ calmodulin/kinase system and arrhythmogenic afterdepolarizations in bradycardia-related acquired long-QT syndrome. Circ Arrhythm Electrophysiol 2009; 2: 295-304.

26 Morita N, Lee JH, Xie Y, Sovari A, Qu Z, Weiss JN, et al. Suppression of re-entrant and multifocal ventricular fibrillation by the late sodium current blocker ranolazine. J Am Coll Cardiol 2011; 57: 366-75.

27 Ashpole NM, Herren AW, Ginsburg KS, Brogan JD, Johnson DE, Cummins TR, et al. $\mathrm{Ca}^{2+} /$ calmodulin-dependent protein kinase II (CaMKII) regulates cardiac sodium channel NaV1.5 gating by multiple phosphorylation sites. J Biol Chem 2012; 287: 19856-69.

28 Zhang Y, Liu Y, Wang T, Li B, Li H, Wang Z, et al. Resveratrol, a natural ingredient of grape skin: antiarrhythmic efficacy and ionic mechanisms. Biochem Biophys Res Commun 2006; 340: 1192-9.

29 Guo D, Lian J, Liu T, Cox R, Margulies KB, Kowey PR, et al. Contribution of late sodium current $\left(I_{\mathrm{Na}-\mathrm{L}}\right)$ to rate adaptation of ventricular repolarization and reverse use-dependence of QT-prolonging agents. Heart Rhythm 2011; 8: 762-9.

30 Yao L, Fan P, Jiang Z, Viatchenko-Karpinski S, Wu Y, Kornyeyev D, et al. Nav1.5-dependent persistent $\mathrm{Na}^{+}$influx activates CaMKII in rat ventricular myocytes and N1325S mice. Am J Physiol Cell Physiol 
2011; 301: C577-86.

31 Coppini R, Ferrantini C, Yao L, Fan P, Del Lungo M, Stillitano F, et al. Late sodium current inhibition reverses electromechanical dysfunction in human hypertrophic cardiomyopathy. Circulation 2013; 127: 575-84.

32 Wagner S, Rokita AG, Anderson ME, Maier LS. Redox regulation of sodium and calcium handling. Antioxid Redox Signal 2013; 18 :
1063-77.

33 Anzai K, Ogawa K, Kuniyasu A, Ozawa T, Yamamoto H, Nakayama $\mathrm{H}$. Effects of hydroxyl radical and sulfhydryl reagents on the open probability of the purified cardiac ryanodine receptor channel incorporated into planar lipid bilayers. Biochem Biophys Res Commun 1998; 249: 938-42. 